\title{
Characterization of the zircon Ce anomaly for estimation of oxidation state of magmas: a revised $\mathrm{Ce} / \mathrm{Ce}{ }^{*}$ method
}

\author{
Shihua Zhong ${ }^{1,2,3}$ (D) $\cdot$ Reimar Seltmann ${ }^{3} \cdot$ Hongying Qu $^{4} \cdot$ Yingxin Song $^{5}$
}

Received: 16 June 2019 / Accepted: 14 August 2019/Published online: 29 August 2019

(C) The Author(s) 2019

\begin{abstract}
As a proxy of magmatic oxidation state, the accurate characterization of the Ce anomaly of zircon is of great significance since it can give important information for provenance studies of rocks as well as for exploration of intrusion-related mineral deposits. The magnitude of the zircon $\mathrm{Ce}$ anomaly has been traditionally described by $\mathrm{Ce} / \mathrm{Ce}^{*}$, where $\mathrm{Ce}^{*}$ is the theoretical $\mathrm{Ce}$ value derived from a chondrite-normalized rare earth element (REE) pattern. More recently, the $\mathrm{Ce}^{4+} / \mathrm{Ce}^{3+}$ method based on the lattice strain model has been proposed, since the latter method does not need La and Pr contents for zircon, both of which are commonly below the limit of detection and susceptible to contamination from melt/mineral inclusions. In this contribution we show that the $\mathrm{Ce}^{4+} / \mathrm{Ce}^{3+}$ method is confronted with some problems in practice and should be further improved. In contrast, by re-examining chondrite-normalized REE patterns of zircon, we find that $\mathrm{Ce}^{*}$ can be estimated according to a logarithmic function curve without involvement of $\mathrm{La}$ and $\mathrm{Pr}$ contents. Application of this new method to zircon data from 11 giant to supergiant porphyry $\mathrm{Cu}$ deposits suggests this revised method as a more valid measure in evaluating magmatic oxidation state. The revised Ce/Ce* method is of particular importance for analyses where the provenance of the analyzed zircon is unknown or in question, since the method does not require knowledge of the melt composition.
\end{abstract}

Keywords $\mathrm{Ce} / \mathrm{Ce}^{*} \cdot$ Zircon $\cdot$ Mineral inclusion $\cdot$ Oxygen fugacity $\cdot$ Porphyry $\mathrm{Cu}$ deposits

\section{Introduction}

As one of the most important physico-chemical parameters of magmas (Barberi et al. 1971), there is a consensus that the oxidation state can act as a valuable archive of geochemical information. For instance, I-type granites are normally characterized by higher oxidation state than $\mathrm{S}$ - type granites (Blevin and Chappell 1992); therefore, geologists can obtain provenance information of magmatic rocks from the oxidation state of the magmas. Also, studies have demonstrated that oxygen fugacity exerts a fundamental control on magma metal fertility for many intrusion-related mineral deposits (Zhong et al. 2017), which are currently the main sources of a number of

Editorial handling: L. Nasdala

Electronic supplementary material The online version of this article (https://doi.org/10.1007/s00710-019-00682-y) contains supplementary material, which is available to authorized users.

Shihua Zhong

zhongshihua@ouc.edu.cn

Hongying Qu

hongyingqu@126.com

1 Key Lab of Submarine Geosciences and Prospecting Techniques, MOE, Institute for Advanced Ocean Study, College of Marine Geosciences, Ocean University of China, Qingdao 266100, China
2 Laboratory for Marine Mineral Resources, Laboratory for Marine Geology and Environment, Qingdao National Laboratory for Marine Science and Technology, Qingdao 266237, China

3 Centre for Russian and Central EurAsian Mineral Studies, Department of Earth Sciences, Natural History Museum, London SW7 5BD, UK

4 MLR Key Laboratory of Metallogeny and Mineral Assessment, Institute of Mineral Resources, Chinese Academy of Geological Sciences, Beijing 100037, China

5 Shandong Institute of Geological Sciences, Jinan 250013, China 
economically important metals on earth (Gardiner et al. 2017).

Zircon $\left(\mathrm{ZrSiO}_{4}\right)$ is an accessory mineral enriched in REEs that is common in igneous rocks of intermediate to felsic composition. Experimental studies have established that Ce enters zircon in both $3+$ and 4+ oxidation states (Trail et al. 2015) and that $\mathrm{Ce}$ (as well as other REEs) will only be incorporated into the $\mathrm{Zr}$ site in the zircon structure (Finch et al. 2001). Owing to these reasons, in chondrite-normalized REE patterns, zircon is commonly characterized by a positive anomaly relative to neighboring $\mathrm{La}$ and $\mathrm{Pr}$ which exclusively form trivalent ions. Compared to $\mathrm{Ce}^{3+}, \mathrm{Ce}^{4+}$ is preferentially incorporated into the zircon structure due to its identical charge and similar size to $\mathrm{Zr}$. Thus, the degree of the Ce anomaly is largely controlled by the oxidation state of the magma, although the water content of the melt, temperature and melt composition also have an influence (Smythe and Brenan 2015). High oxygen fugacity will oxidize $\mathrm{Ce}^{3+}$ to $\mathrm{Ce}^{4+}$ and permits more $\mathrm{Ce}$ to be incorporated into the zircon crystal structure, thus resulting in greater $\mathrm{Ce}$ anomalies in chondrite-normalized patterns. This relationship between zircon $\mathrm{Ce}^{4+} / \mathrm{Ce}^{3+}$ and magmatic oxygen fugacity has now been firmly demonstrated by experimental studies (Burnham and Berry 2012; Trail et al. 2012; Trail et al. 2011; Smythe and Brenan 2016).

As a proxy for the oxidation state of magmas, a reliable characterization of the zircon Ce anomaly appears merited and has now attracted the interest of many geologists. The $\mathrm{Ce}$ anomaly was generally estimated using $\mathrm{La}$ and $\mathrm{Pr}$ concentrations (e.g., Claiborne et al. 2010; Munoz et al. 2012; Gardiner et al. 2017). This method was recently revised by Ballard et al. (2002) and Loader et al. (2017). In the study of Loader et al. (2017), Nd and Sm replacing La and Pr were used in the calculation procedure for the zircon Ce anomaly. They stated that their revised method was more robust than that conventionally used as it did not need precise analyses of La and $\mathrm{Pr}$ contents for zircons, both of which are commonly below the limit of detection and susceptible to contamination from mineral inclusions. Alternatively, zircon Ce anomaly can be described using $\mathrm{Ce}^{4+} / \mathrm{Ce}^{3+}$. Trail et al. (2015) argued that $\mathrm{Ce}$ valence of zircon could be directly measured by X-ray Absorption Near Edge Structure (XANES). Nevertheless, direct determination of zircon $\mathrm{Ce}^{4+} / \mathrm{Ce}^{3+}$ by spectroscopic methods is now less common in literature because $\gamma$ irradiation experiments suggest that decrease of $\mathrm{Ce}^{4+}$ will occur due to the reductive reaction of $\mathrm{Ce}^{4+}$ to $\mathrm{Ce}^{3+}$ by the radiation effect of $U$ and $T h$ in the zircon (Takahashi et al. 2003). Ballard et al. (2002) proposed an indirect method to describe zircon $\mathrm{Ce}^{4+} / \mathrm{Ce}^{3+}$ ratios according to the lattice strain model. Compared to the $\mathrm{Ce} / \mathrm{Ce}^{*}$ method, Ballard et al.' method may be less sensitive to contamination from light REE (LREE)enriched inclusions since it no longer depends on just a pair of LREEs (La-Pr or Nd-Sm), but it needs REE compositions of not only zircons but also melts from which these zircons crystallized.

In this study, using published databases for zircon, we compare these different methods in characterizing zircon $\mathrm{Ce}$ anomalies for estimation of the oxidation state of magmas. It is shown that the above methods are yet neither satisfactory nor convincing, and in some cases may provide misleading information for oxidation state of magmas. By re-examining the chondrite-normalized REE patterns of zircon, a revised method to describe zircon $\mathrm{Ce}$ (and also $\mathrm{Eu}$ ) anomalies is proposed. We demonstrate that the revised method in this study is valid and sensitive in examining magmatic oxidation state.

\section{The $\mathrm{Ce}^{4+} / \mathrm{Ce}^{3+}$ method}

\section{The crystal lattice strain model}

According to the method of Ballard et al. (2002), the total concentrations of $\mathrm{Ce}$ in zircon and co-existing melt can be considered as sums of $\mathrm{Ce}^{3+}$ and $\mathrm{Ce}^{4+}$ in each phase:

$$
\begin{aligned}
& \mathrm{Ce}_{\text {zircon }}=\mathrm{Ce}_{\text {zircon }}^{3+}+\mathrm{Ce}_{\text {zircon }}^{4+} \\
& \mathrm{Ce}_{\text {melt }}=\mathrm{Ce}_{\text {melt }}^{3+}+\mathrm{Ce}_{\text {melt }}^{4+}
\end{aligned}
$$

By introducing partition coefficients $\left(\mathrm{D}_{\mathrm{Ce}^{3+}}^{\text {zircon/melt }}\right.$ and $\mathrm{D}_{\mathrm{Ce}^{4+}}^{\text {ziron }}$ ) for $\mathrm{Ce}^{3+}$ and $\mathrm{Ce}^{4+}$, respectively, Eqs. 1 and 2 can be then substituted, combined and rearranged to produce the following expression:

$$
\left(\frac{\mathrm{Ce}^{4+}}{\mathrm{Ce}^{3+}}\right)_{\text {zircon }}=\frac{\mathrm{Ce}_{\text {melt }}-\frac{\mathrm{Ce}_{\text {zircon }}}{\mathrm{D}_{\mathrm{Ce}^{3+}}^{\text {zircon } / \text { melt }}}}{\frac{\mathrm{Ce}_{\text {zircon }}}{\mathrm{D}_{\mathrm{Ce}^{4+}}^{\text {ziron } / \text { melt }}}-\mathrm{Ce}_{\text {melt }}}
$$

where $\mathrm{Ce}_{\text {zircon }}$ can be measured directly by laser ablationinductively coupled plasma-mass spectrometry (LA-ICPMS) or secondary ion mass spectrometry (SIMS) methods; whole rock $\mathrm{Ce}$ is suggested as an equivalent of $\mathrm{Ce}_{\text {melt }}$; and $\mathrm{D}_{\mathrm{Ce}^{3+}}^{\text {ziron }}$ melt and $\mathrm{D}_{\mathrm{Ce}^{4+}}^{\text {zircon/melt }}$ can be calculated using the lattice strain model proposed by Blundy and Wood (1994).

According to the lattice strain model, for an isovalent series of ions with charge $n+$ and radius $r_{\mathrm{i}}$ entering the crystal lattice site, the partition coefficient, $D_{\mathrm{i}}$, can be described in terms of three parameters (Eq. 3): $r_{0}^{\mathrm{n}+}$, the optimum radius of that site; $E^{\mathrm{n}+}$, the Young's Modulus of that site caused by ions that are bigger or smaller than $r_{0}^{\mathrm{n}+}$; and $D_{0}^{\mathrm{n}+}$, the "strain-compensated" partition coefficient for a (fictive) ion with radius $r_{0}^{\mathrm{n}+}$ :

$$
\ln \mathrm{D}_{\mathrm{i}}=\ln \mathrm{D}_{0}^{\mathrm{n}+}-\frac{4 \pi \mathrm{N}_{\mathrm{A}} \mathrm{E}^{\mathrm{n}+}}{\mathrm{RT}}\left(\frac{\mathrm{r}_{\mathrm{i}}}{3}+\frac{\mathrm{r}_{0}^{\mathrm{n}+}}{6}\right)\left(\mathrm{r}_{\mathrm{i}}-\mathrm{r}_{0}^{\mathrm{n}+}\right)^{2}
$$


where $\mathrm{N}_{\mathrm{A}}$ is Avogadro's Number, $\mathrm{R}$ is the universal gas constant and $\mathrm{T}$ is in $\mathrm{K}$.

When plotted according to Eq. 4, linear arrays can be found on a $\ln D_{i}$ versus $\left(\frac{\mathrm{r}_{\mathrm{i}}}{3}+\frac{\mathrm{r}_{0}^{\mathrm{n}+}}{6}\right)\left(\mathrm{r}_{\mathrm{i}}-\mathrm{r}_{0}^{\mathrm{n}+}\right)^{2}$ plot for an isovalent series of ions. By fitting these lines to trivalent REE and tetravalent $\mathrm{Zr}$-Hf-U-Th arrays, values for $\mathrm{D}_{\mathrm{Ce}^{3+}}^{\text {zircon/melt }}$ and $\mathrm{D}_{\mathrm{Ce}}^{\mathrm{zircon} / \mathrm{melt}}$ can be estimated. The resulting partition coefficients for $\mathrm{Ce}^{3+}$ and $\mathrm{Ce}^{4+}$ can be substituted into Eq. 3 and used in the calculation of the $\mathrm{Ce}^{4+} / \mathrm{Ce}^{3+}$ values. A similar procedure can be applied to $\mathrm{Eu}$, which is also an important $\mathrm{REE}$ with variable valences $\left(\mathrm{Eu}^{2+}\right.$ and $\left.\mathrm{Eu}^{3+}\right)$.

\section{Assessment of assumptions for $\mathrm{Ce}^{4+} / \mathrm{Ce}^{3+}$ calculation}

According to the procedure of Ballard et al. (2002), two assumptions have to be made to obtain $\mathrm{Ce}^{4+} / \mathrm{Ce}^{3+}$ values by the lattice strain model. Firstly, whole rock geochemistry is assumed to be identical to melts from which zircon crystalizes, so whole rock REE (as well as Hf, Th, U, Zr) data can be used as a proxy for melt chemistry when calculating $\mathrm{D}_{\mathrm{i}}$. Secondly, REEs and tetravalent cations (including $\mathrm{Hf}$, Th and $\mathrm{U}$ ) will only substitute the $\mathrm{Zr}$ site in zircon crystals, thus in previous studies it was assumed that both $\mathrm{r}_{0}^{3+}$ and $\mathrm{r}_{0}^{4+}$ were identical to the ionic radius of $\mathrm{Zr}$ in eight-fold coordination $(0.84 \AA)$.

Unfortunately, the first assumption has been demonstrated untenable. By studying zircon samples from the world class Oyu Tolgoi porphyry $\mathrm{Cu}-\mathrm{Au}$ deposit, Loader et al. (2017) demonstrated that if titanite crystallization precedes or accompanies zircon crystallization, $\mathrm{REE}_{\text {melt }}$ would be lower than $\mathrm{REE}_{\mathrm{WR}}$, causing estimates of $\mathrm{Ce}^{4+} / \mathrm{Ce}^{3+}$ to be erroneously high. Crystallization of other accessory minerals, e.g., apatite and monazite, which are also common REE-enriched minerals in magmatic rocks, may play a similar role in affecting melt compositions from which zircon crystallized. Besides, zircons from many intrusions record a protracted and complex history of fractional crystallization and crustal assimilation, and thus even zircons from the same hand specimens may be characterized by distinct melt compositions (Claiborne et al. 2010). Therefore, using whole rock data as a proxy for melt compositions is inherently problematic under certain circumstances.

The second assumption is also problematic. According to Eq. 4, an inverse parabolic distribution can be expected in an ionic radius versus $\ln$ Di diagram (also called Onuma diagram) for isovalent ions entering the $\mathrm{Zr}$ site, and that the "best-fit" ion should have a radius $\mathrm{r}_{0}^{\mathrm{n}+}$ and a corresponding partition coefficient $\mathrm{D}_{0}^{\mathrm{n}+}$ at the peak of the parabola (Fig. 1). However, Blundy and Wood (1994) argued that values for the optimum site radius, $\mathrm{r}_{0}^{\mathrm{n}+}$, were not necessarily the same as the radius of the cation normally resident at the site of interest. Wood and Blundy (1997) further pointed out that $\mathrm{r}_{0}^{\mathrm{n}+}$ was actually sensitive to variations of crystal composition,

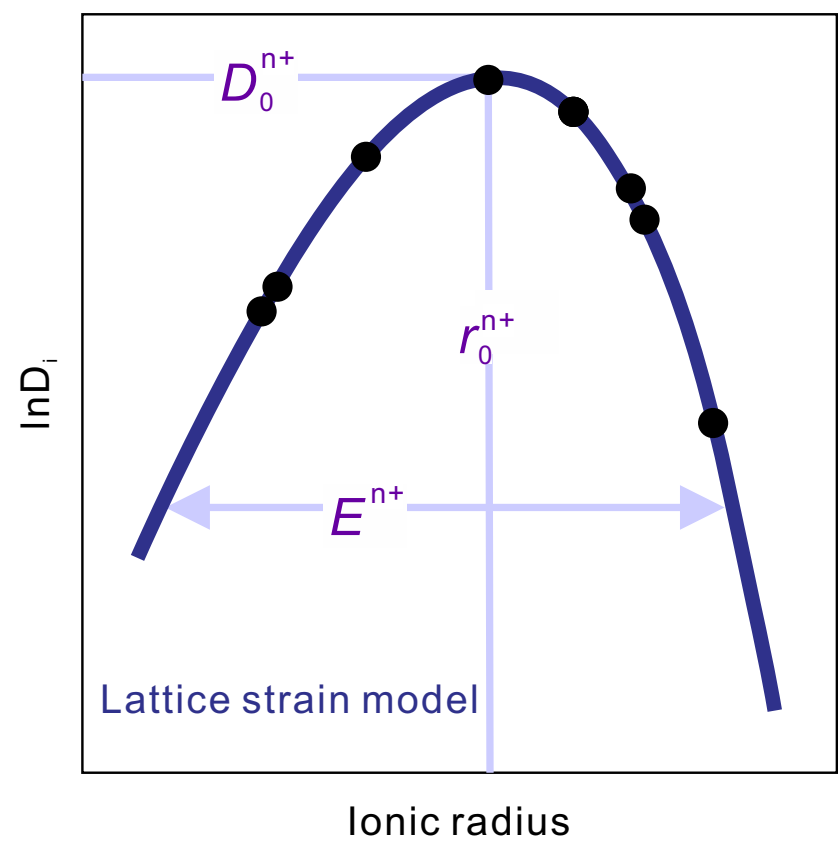

Fig. 1 Cartoon illustrating the lattice strain model for isovalent ions entering into a zircon crystal (modified after Blundy and Wood 2003)

as well as temperature and pressure. To find the real $\mathrm{r}_{0}^{3+}$ for zircon is not a trivial matter since changing $r_{0}^{3+}$ will result in variations of zircon $\mathrm{Ce}^{4+} / \mathrm{Ce}^{3+}$ values and determine to what degree rocks with different oxidation state of magmas can be distinguished using $\mathrm{Ce}^{4+} / \mathrm{Ce}^{3+}$ (Fig. 2). In the following section, we demonstrate that using the radius of $\mathrm{Zr}(0.84 \AA)$ to replace $\mathrm{r}_{0}^{3+}$ in the procedure of Ballard et al. (2002) is not accurate.

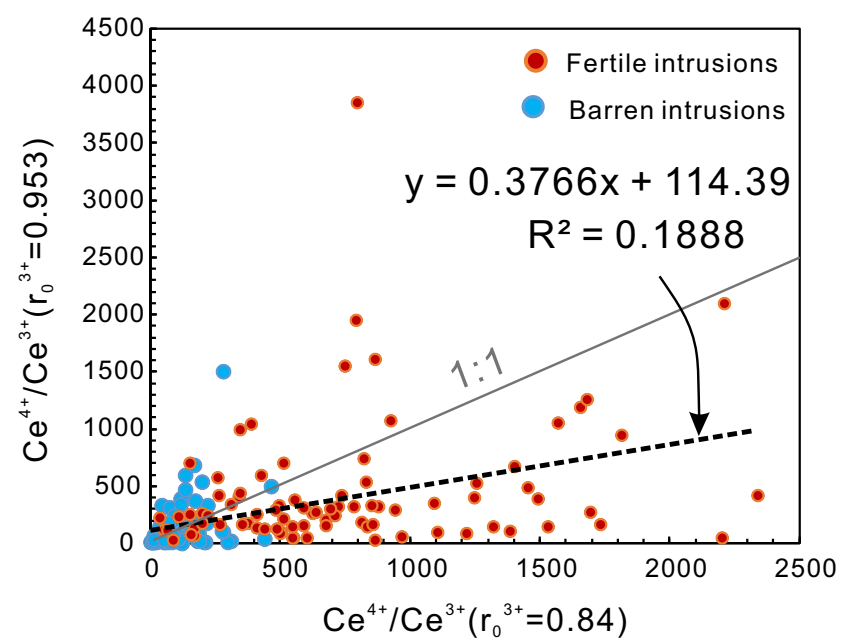

Fig. 2 Comparison of zircon $\mathrm{Ce}^{4+} / \mathrm{Ce}^{3+}$ values calculated by assuming $\mathrm{r}_{0}^{3+}=0.84$ and 0.953 , respectively. $\mathrm{r}_{0}^{3+}=0.953$ was chosen for comparison according to the second section. The low coefficient of determination $\left(\mathrm{R}^{2}=0.1888\right)$ indicates that the change of $\mathrm{r}_{0}^{3+}$ will result in unpredictable variations of zircon $\mathrm{Ce}^{4+} / \mathrm{Ce}^{3+}$ values. Zircon data are from porphyry copper deposits of northern Chile (Ballard et al. 2002), with fertile and barren intrusions representing magmas of high and low oxidation state, respectively 


\section{Revised $\mathrm{r}_{0}^{3+}$ for zircon}

In Online Resource 1, trace element data of a total of 35 experimental and natural zircon samples were considered to examine the optimum radius $\left(\mathrm{r}_{0}^{\mathrm{n}+}\right)$ for ions substituting the $\mathrm{Zr}$ site of zircon lattice. They were complied from publications of Burnham and Berry (2012); Colombini et al. (2011); Luo and Ayers (2009); Mahood and Hildreth (1983); Marshall et al. (2009); Murali et al. (1983); Sano et al. (2002) and Thomas et al. (2002). This database was chosen because not only zircon, but also melt compositions (by analyzing co-existing groundmass in volcanic rocks or melt inclusions) were measured directly, thus giving exact estimation for partition coefficients of trace elements. In this table, $\mathrm{r}_{0}^{3+}$ values were calculated by fitting the partition coefficients of trivalent REE (and Sc where possible) ions to a parabolic curve in the Onuma diagram.

Variations of $\mathrm{r}_{0}^{3+}$ are observed between samples and between different zircon crystals from the same samples. Nevertheless, the majority of $\mathrm{r}_{0}^{3+}$ values for zircon crystals range from 0.914 to $1.010 \AA$, which are significantly greater than the radius for $\mathrm{Zr}(0.84 \AA)$ (Fig. 3). Only data from Thomas et al. (2002) show $\mathrm{r}_{0}^{3+}$ values smaller than $0.84 \AA$, which however may not be convincing because only a few REEs were reported in their study and thus cannot constrain the parabola well. Figures 1 and 3 manifests that if there is no

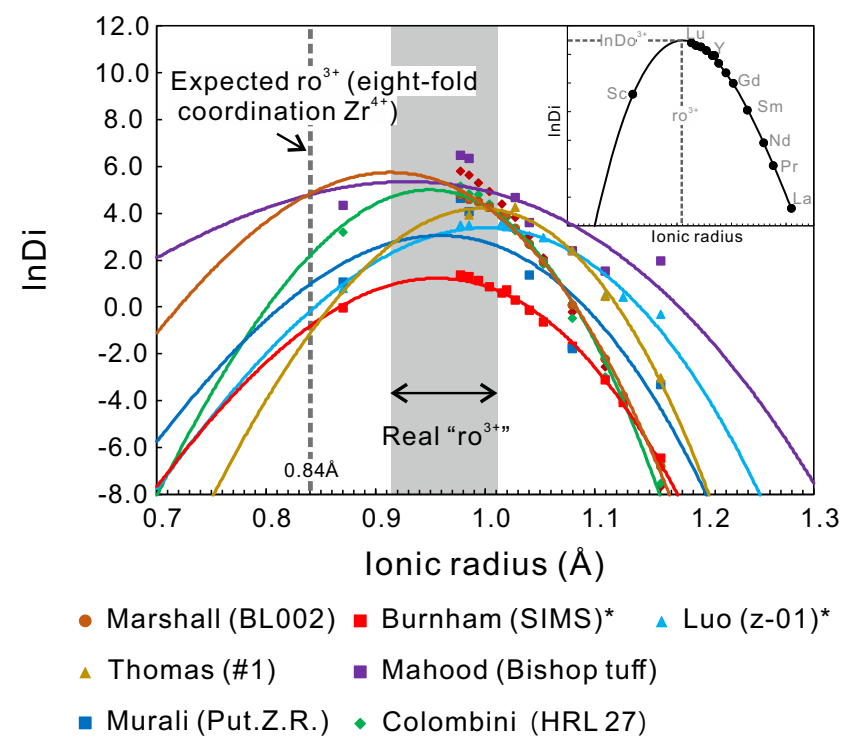

Fig. 3 Onuma diagrams showing the parabola was obtained by fitting the reported zircon/melt partition coefficients of REEs (plus Y and Sc) to the lattice strain model of Blundy and Wood (1994). Information in legends corresponds to data sources and sample names (see Online Resource 1 for more details). The asterisk indicates data were from experimental samples, whereas others from natural samples. Ce and $\mathrm{Eu}$ were not included because they are susceptible to oxidation condition and/or feldspar fractionation, respectively. The inserted figure is a cartoon illustrating the lattice strain model of trace element partitioning for a crystal element with $\mathrm{r}_{\mathrm{i}}^{3+}<\mathrm{r}_{0}^{3+}$, the predicted $\mathrm{r}_{0}^{3+}$ by the lattice strain model will also be inaccurate (Blundy and Wood 2003). In Online Resource 1 , only five zircon grains from Colombini et al. (2011) and Burnham and Berry (2012) reported $D_{\mathrm{Sc}}$ $\left(r_{S c}=0.87 \AA\right)$ and the full REEs simultaneously, giving a narrow range from 0.948 to $0.959 \AA$ with an average of $0.953 \AA$. This value is currently the best estimation for zircon $\mathrm{r}_{0}^{3+}$. A recent study for zircon by Smythe and Brenan (2016) also found the $\mathrm{Zr}$ radius could not represent the true $\mathrm{r}_{0}^{3+}$. They used $\mathrm{r}_{0}^{3+}=0.93 \AA$ in their zircon $\mathrm{Ce}^{4+} / \mathrm{Ce}^{3+}$ calculation, which is almost identical to the result from this study. All these indicate that "real" $\mathrm{r}_{0}^{3+}$ for zircon should be at least greater than $0.84 \AA$.

The $\mathrm{r}_{0}^{4+}$ values, however, cannot be estimated in the same way as for $\mathrm{r}_{0}^{3+}$, because there are too few elements (normally $\mathrm{Hf}, \mathrm{Th}, \mathrm{U}$ and $\mathrm{Zr}$ ) to constrain the parabolas for tetravalent ions. Nonetheless, unlike $\mathrm{r}_{0}^{3+}$, the assumption that $\mathrm{r}_{0}^{4+}=$ $0.84 \AA$ may be reasonable. Since $r_{\mathrm{Hf}}<r_{\mathrm{Zr}}>r_{\mathrm{Th}, \mathrm{U}}$ and for most terrestrial zircons $\mathrm{D}_{\mathrm{Zr}}>\mathrm{D}_{\mathrm{Hf}, \mathrm{Th}, \mathrm{U}}$, it is not hard to see from Fig. 1 that the "best-fit" tetravalent ion entering into zircon may have a radius similar to $\mathrm{Zr}$.

It should be noted that $\mathrm{D}_{\mathrm{REE}}$ was found to be related to temperature (e.g., Rubatto and Hermann 2007), and therefore the calculated $\mathrm{r}_{0}^{3+}$ values, according to the lattice strain model, may vary according to the melt temperatures. However, a correlation between the calculated $\mathrm{r}_{0}^{3+}$ values and melt temperatures is not observed (see Online Resource 1), ruling out that the observed high $\mathrm{r}_{0}^{3+}$ values reflect discrepancies due to melt temperatures. Nevertheless, considering the variations of $\mathrm{r}_{0}^{3+}$ observed in Online Resource 1, we recommend using $\mathrm{r}_{0}^{3+}$ $=0.954 \AA$ in calculation of zircon $\mathrm{Ce}^{4+} / \mathrm{Ce}^{3+}$ only after it is further verified by more experimental studies, or we suggest that $\mathrm{r}_{0}^{3+}$ must be determined by regression in each case. In either case, using the method of Ballard et al. (2002) to calculate zircon $\mathrm{Ce}^{4+} / \mathrm{Ce}^{3+}$ may be problematic in practice, and caution must be taken when using it to evaluate oxidation state of magmas.

\section{Alternative method to calculate $\mathrm{Ce}^{4+} / \mathrm{Ce}^{3+}$}

Rearrangement of Eq. 3 can give the following equation:

$\ln \mathrm{D}_{\mathrm{i}}=\frac{\mathrm{A}}{6}\left[-2 \mathrm{r}_{\mathrm{i}}^{3}+3 \mathrm{r}_{0}^{\mathrm{n}+} \mathrm{r}_{\mathrm{i}}^{2}+\left(\frac{6}{\mathrm{~A}} \ln \mathrm{D}_{0}^{\mathrm{n}+}-\left(\mathrm{r}_{0}^{\mathrm{n}+}\right)^{3}\right)\right]$

where $\mathrm{A}=\frac{4 \pi \mathrm{N}_{\mathrm{A}} \mathrm{E}^{\mathrm{n}+}}{\mathrm{RT}}$; and $\ln \mathrm{D}_{0}^{\mathrm{n}+}$ and $\mathrm{r}_{0}^{\mathrm{n}+}$ are both constants for a given zircon crystal.

Thus, Eq. 5 can be regarded as a cubic function in the form $\mathrm{f}(\mathrm{x})=\mathrm{ax}^{3}+\mathrm{cx}^{2}+\mathrm{d}$, where $\mathrm{f}(\mathrm{x})=\ln \mathrm{D}_{\mathrm{i}}$ and $\mathrm{x}=\mathrm{r}_{\mathrm{i}}$. When $\ln \mathrm{D}_{\mathrm{i}}$ and $r_{i}$ are plotted according to Eq. 5, a parabola can be obtained in the Onuma diagram, by which $\mathrm{D}_{\mathrm{Ce}^{3+}}^{\text {zircon/melt }}$ can be 
estimated directly without assigning a value to $\mathrm{r}_{0}^{3+}$. The same method was used by Burnham and Berry (2017). $\mathrm{D}_{\mathrm{Ce}^{4+}}^{\text {zircon/melt }}$ can be estimated in a similar way. By substituting the partition coefficients for $\mathrm{Ce}^{4+}$ and $\mathrm{Ce}^{3+}$ into Eq. 3, the $\mathrm{Ce}^{4+} / \mathrm{Ce}^{3+}$ ratio can be calculated.

However, this method should still be used with caution, since the exact melt composition from which zircon crystalized is still needed in the calculation process. Also, Sc contents of zircon and melts are needed to constrain the $\mathrm{r}_{0}^{3+}$ (and thus the parabola for trivalent ions), but unfortunately most studies of zircon do not report Sc (Burnham and Berry 2012). This is partly due to the analysis of Sc concentrations in zircon being complicated because, in addition to ${ }^{29} \mathrm{Si}^{16} \mathrm{O}$, ${ }^{90} \mathrm{Zr}^{2+}$ interferes with Sc at mass 45 (Wopenka et al. 1996).

\section{The $\mathrm{Ce} / \mathrm{Ce}^{*}$ method}

\section{The existing methods}

The most classic method to quantify $\mathrm{Ce}$ anomaly is $\mathrm{Ce} / \mathrm{Ce} *$, where $\mathrm{Ce}^{*}=\sqrt{\mathrm{La}_{\mathrm{N}} \times \operatorname{Pr}_{\mathrm{N}}}$ (the subscript indicates chondrite normalization). However, La and Pr are very low in abundance and frequently below the limit of detection. Therefore, this method often incurs criticism where used, since it is susceptible to contamination by small LREE-enriched melt/ mineral inclusions that are common in zircon (Bindeman et al. 2014). Loader et al. (2017) modified the traditional method and proposed an alternative formulation for $\mathrm{Ce}^{*}$, based on a similar geometric relationship previously used:

$\mathrm{Nd}_{\mathrm{N}}=\sqrt{\mathrm{Ce}^{*} \times \mathrm{Sm}_{\mathrm{N}}}$

which, when rearranged, yields an expression for $\mathrm{Ce}^{*}$,:

$\mathrm{Ce}^{*}=\frac{\mathrm{Nd}_{\mathrm{N}}^{2}}{\mathrm{Sm}_{\mathrm{N}}}$

This formulation does not require the accurate determination of either La or Pr, thus it is believed to be more robust than the conventional method. However, many studies have argued that in chondrite-normalized REE patterns, zircons REEs show a concave-downwards shape, rather than a linear shape. Thus, both $\sqrt{\mathrm{La}_{\mathrm{N}} \times \operatorname{Pr}_{\mathrm{N}}}$ and $\frac{\mathrm{Nd}_{\mathrm{N}}^{2}}{\mathrm{Sm}_{\mathrm{N}}}$ are not the best estimation for $\mathrm{Ce}^{*}$, and will result in underestimation (the conventional method) or overestimation (Loader et al.'s (2017) method) of the true Ce*. Besides, Loader et al. (2017) showed that $\mathrm{Ce} / \mathrm{Ce}^{*}$ calculated by their method showed a great overlap between fertile and barren rocks, indicating that it is not a robust tool for estimation of the oxidation state of magmas.

\section{Revised $\mathrm{Ce} / \mathrm{Ce}^{*}$ method by this study}

To determine $\mathrm{Ce}^{*}$, the key is to find a function which can perfectly match the position of LREEs and middle REEs (MREEs) with $3+$ cations in the chondrite-normalized REE pattern for zircon. We therefore examined ca. 1000 zircon trace element data from intrusions in 11 giant to supergiant porphyry $\mathrm{Cu}(-\mathrm{Au})$ deposits worldwide. Complied descriptions about these deposits and literature sources were listed in Online Resource 2. In this study, La to $\mathrm{Lu}$ (15 elements) were assigned numbers 1 to 15 (Pm was 5 although it does not exist in nature) in the chondrite-normalized REE pattern. Regression calculation clearly shows that REE patterns of zircons from Online Resource 2 can be matched by the logarithmic function $(y=\operatorname{alog}(x)+b$, where $y$ is the logarithm (base 10) of chondrite-normalized REEs) (Fig. 4), with more than $99 \%$ of 847 fitting curves characterized by the coefficient of determination $\left(\mathrm{R}^{2}\right)$ of $>0.95$ (Online Resource 2 ). It should be noted that during the regression calculation La and Pr were not included due to their uncertain concentrations. With these fitting curves, $\mathrm{Ce}^{*}$ as well as Eu* (previously constrained by $\sqrt{\mathrm{Sm}_{\mathrm{N}} \times \mathrm{Gd}_{\mathrm{N}}}$ ) can be precisely determined.

Using this revised method, we re-calculated zircon $\mathrm{Ce} / \mathrm{Ce}$ * and $\mathrm{Eu} / \mathrm{Eu}^{*}$ values from 11 porphyry $\mathrm{Cu}(-\mathrm{Au}$ ) deposits (see Online Resource 2 for more details). Compared to the existing method, both $\mathrm{Ce} / \mathrm{Ce}^{*}$ and $\mathrm{Eu} / \mathrm{Eu}^{*}$ values calculated by the revised method show a much narrower range (Fig. 5). Moreover, although zircon $\mathrm{Ce} / \mathrm{Ce}^{*}$ and $\mathrm{Eu} / \mathrm{Eu}^{*}$ values calculated by either method exhibit some overlaps between barren and fertile intrusions, those calculated by the revised method behave more regularly and can more clearly distinguish fertile

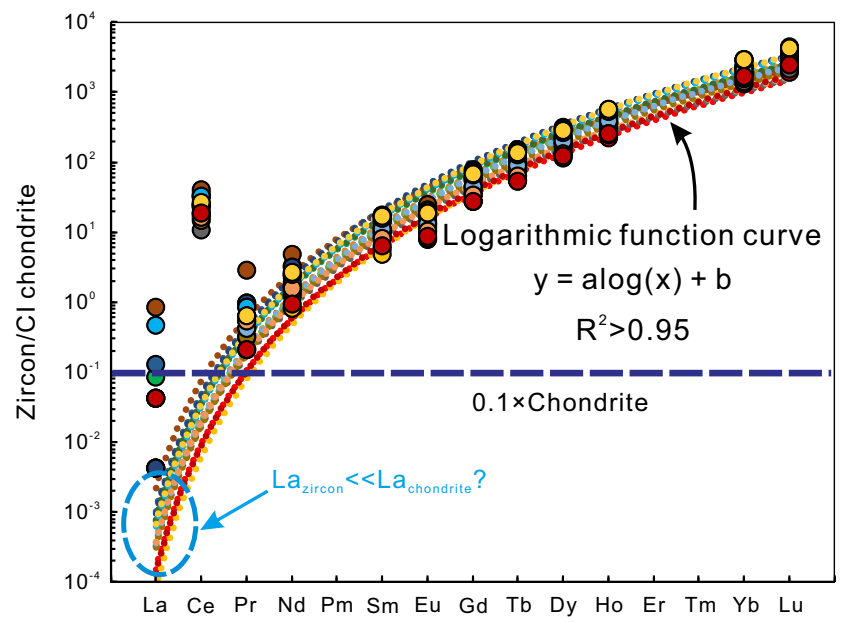

Fig. 4 Chondrite-normalized REE patterns for zircon from the Bozshakol porphyry $\mathrm{Cu}$ deposit, Kazakhstan (Shen et al. 2015). All these zircon REE compositions can be well described by logarithmic function curves with high coefficient of determination $\left(\mathrm{R}^{2}>0.95\right)$. Note that $\mathrm{La}, \mathrm{Ce}, \mathrm{Pr}$ and Eu were not involved during the regression calculation. The fitting curves seem to support that the La concentration of natural zircon should be far below that of chondrite $(0.237 \mathrm{ppm})$. CI chondrite data are from McDonough and Sun (1995) 

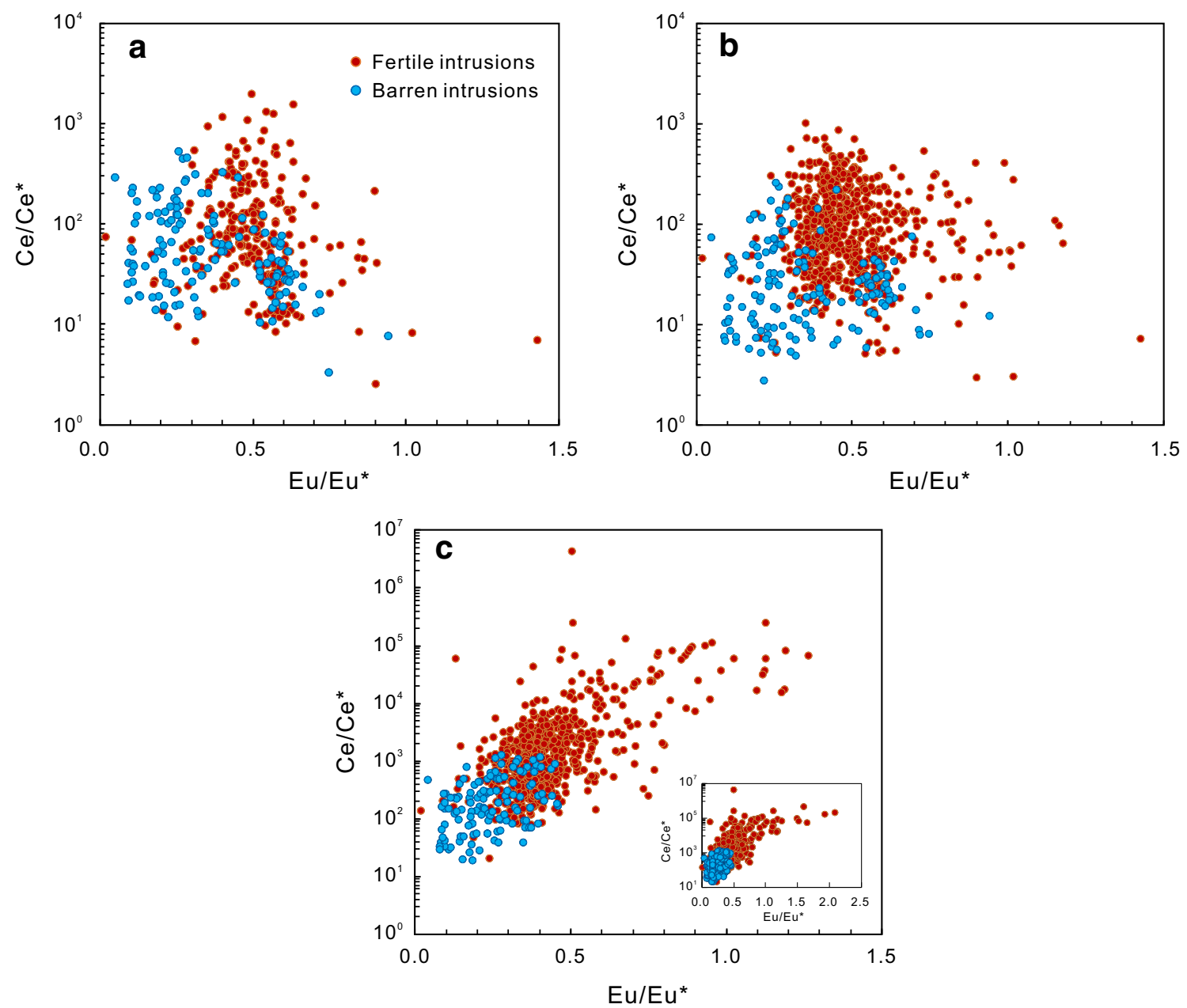

Fig. 5 Comparison of different methods in calculating zircon $\mathrm{Ce}$ and $\mathrm{Eu}$ anomalies. Zircon data were from 11 giant to supergiant porphyry $\mathrm{Cu}(-$ $\mathrm{Au}$ ) deposits, where fertile and barren intrusions had been demonstrated related to magmas of high and low oxidation state, respectively. (a) $\mathrm{Ce} /$ $\mathrm{Ce}^{*}$ and $\mathrm{Eu} / \mathrm{Eu}^{*}$ were calculated by the conventional method following the formulas: $\mathrm{Ce}^{*}=\sqrt{\mathrm{La}_{\mathrm{N}} \times \operatorname{Pr}_{\mathrm{N}}}$ and $\mathrm{Eu}^{*}=\sqrt{\mathrm{Sm}_{\mathrm{N}} \times \mathrm{Gd}_{\mathrm{N}}}$. (b) $\mathrm{Eu}^{*}$ was

from barren intrusions (Fig. 5). Since the high oxygen fugacities of the fertile intrusions in these porphyry deposits have been demonstrated previously, all these data manifest the advantages of the revised method in determining magmatic oxidation state and distinguishing between fertile and barren intrusions for porphyry $\mathrm{Cu}$ systems.

\section{Implication for La entering into zircon lattice}

Figure 4 shows that the predicted La values $(<0.001 \mathrm{ppm})$ by the logarithmic function curve for zircon from the Bozshakol porphyry $\mathrm{Cu}$ deposit are far below the measured values (0.001-0.20 ppm) (Online Resource 2; Shen et al. 2015). In Online Resource 2, predicted zircon La values for ten other deposits display a similar behavior and are all far below calculated using the conventional method, whereas $\mathrm{Ce}^{*}$ follows the procedure proposed by Loader et al. (2017). (c) $\mathrm{Ce}^{*}$ and $\mathrm{Eu}^{*}$ were calculated by the revised method in this study by fitting zircon REE data to logarithmic function curves. The insert represents the full results which show a large range of $\mathrm{Eu} / \mathrm{Eu}^{*}$

$0.03 \mathrm{ppm}$ ( $\sim 0.1$ times that for chondrite). A similar case is found for Pr.

The following scenario may account for the deviation of the measured La (as well as Pr) concentrations from the fitting lines: (1) inapplicability of the logarithmic function in describing the zircon REE behaviors; (2) contamination from LREEenriched minerals in the measured La values; and (3) modification by hydrothermal alteration of the measured zircon. The fitting logarithmic function lines obtained in our study are characterized by very high $\mathrm{R}^{2}(>0.95)$, which indicates that they can describe the behaviors of REEs. Nevertheless, it is quite possible that the logarithmic function line found in our study is not applicable to hydrothermal zircon, considering that zircon-fluid partition coefficients for REEs may be quite different from zircon-melt partition coefficients. Theoretically, it is possible that hydrothermal alteration can explain the abnormally elevated $\mathrm{La}$ and $\mathrm{Pr}$ contents measured in some 
zircons if zircon-fluid partition coefficients for La and Pr are higher than their zircon-melt partition coefficients. However, direct experimental data are absent to demonstrate that zircon crystallized from fluid can have higher La and Pr partition coefficients. Besides, based on petrographic observation, trace element compositions and ages of those zircons, hydrothermal alteration on these studied zircons had been excluded (Ballard et al. 2002; Loader et al. 2017; Munoz et al. 2012; Shen et al. 2015; Zhu et al. 2018).

Therefore, the most likely explanation for the high La and Pr content in some natural zircons versus the modelled values is contamination by mineral, fluid and/or melt inclusions. Zhong et al. (2018) showed at least one case where abundant mineral inclusions are present in zircon, some of which were supposedly sub-micrometer in size and hard to monitor during the zircon trace element analysis. They demonstrated that only 0.05 vol.\% contamination from those small LREE-enriched mineral inclusions (e.g., apatite and titanite) would result in evident elevation of $\mathrm{La}$ and $\mathrm{Pr}$ for zircon. Thus, it is quite possible that the deviation of predicted La contents by the logarithmic function from measured La contents just results from mineral inclusion contamination in zircon during in situ microanalysis (Fig. 4 and Online Resource 2). If this conclusion is correct and $\mathrm{La}=0.03 \mathrm{ppm}$ is taken as a critical value for clean zircon, approximately $40 \%$ of zircons in Online Resource 2 suffered contamination from LREEenriched minerals during the analysis process. We thus suggest that $\mathrm{La}$ entering into zircon is much lower than what commonly measured, and that accidental sampling of melt/ mineral inclusions during the zircon trace element analysis is very common due to their widespread occurrence and small sizes.

It should be noted that a recent study by Zou et al. (2019) also proposed a cut-off La value ( $<0.1 \mathrm{ppm}$ ) for inclusion-free zircon based on a compilation of zircon data from the GEOROC database (which shows that most zircons are characterized by La contents as low as $0.1 \mathrm{ppm}$ ). According to our study, La entering into zircon should be much lower than this value and most zircon trace element data (at least for LREEs) in the GEOROC database appear to be contaminated by LREE-enriched melt/mineral inclusions.

\section{Advantages and applications}

The revised $\mathrm{Ce} / \mathrm{Ce}^{*}$ method introduced by our study shows some advantage in calculation of the Ce anomaly and evaluation of the oxidation state of magmas. Compared to the $\mathrm{Ce}^{4+} /$ $\mathrm{Ce}^{3+}$ methods, the revised $\mathrm{Ce} / \mathrm{Ce} *$ method does not involve melt composition which is generally inaccessible for intrusive rocks and detrital zircons. Also, our method only requires REE concentrations in zircon when compared to Ballard et al. (2002) that requires some less constrained parameters (e.g., $\mathrm{r}_{0}^{\mathrm{n}+}$ ), which can result in high errors of the calculated $\mathrm{Ce}^{4+} / \mathrm{Ce}^{3+}$. Furthermore, using published databases for zircon, our study shows that the new method is more valid in discriminating the oxidation state of different magmas.

However, the presented method still should be used carefully when evaluating the magmatic oxidation state. Points to keep in mind are other possible controls on the Ce anomaly apart from $\mathrm{fO}_{2}$ of magmas and the behaviors of LREE entering into zircon. Current studies have illustrated that the $\mathrm{Ce}$ anomaly is not just a function of $f \mathrm{O}_{2}$, but also of the water content of the melt, temperature and melt composition (Smythe and Brenan 2015). This may explain why in Fig. 5c there is still an overlapping area between barren and fertile samples. Nevertheless, the water content of melt, temperature and melt composition seem to play a less predominant role on the $\mathrm{Ce}$ anomaly compared to $f \mathrm{O}_{2}$. Figure 6 shows the variations of $\mathrm{Ce}^{4+} / \mathrm{Ce}^{3+}$ of $\mathrm{Ce}$ doped glasses with $\mathrm{fO}_{2}$ from Smythe and Brenan (2015). These glasses varied in composition (basalt to rhyolite) and were synthesized under quite different temperatures $\left(1200\right.$ to $\left.1500^{\circ} \mathrm{C}\right)$, water contents $(<2.8$ to $9.1 \mathrm{wt} \%)$ and oxidation states (FMQ -4.0 to FMQ +8.4). It shows that although the water content, temperature and melt composition are quite different, the Ce anomaly and $f \mathrm{O}_{2}$ of synthesized glasses still show a strong correlation. Same information can also be gained by examining the coefficients of Eq. 15 in Smythe and Brenan (2015). This means that despite probably being defective, using the Ce anomaly to reflect the degree of $\mathrm{fO}_{2}$ is still feasible in practice.

The lack of the exact knowledge on the behaviors of LREE entering into zircon is a limiting factor for the use of the method (and also for all other existing methods using the zircon Ce anomaly to evaluate $f \mathrm{O}_{2}$ ). Fundamental to our new method is the assumption of the consistent mechanism

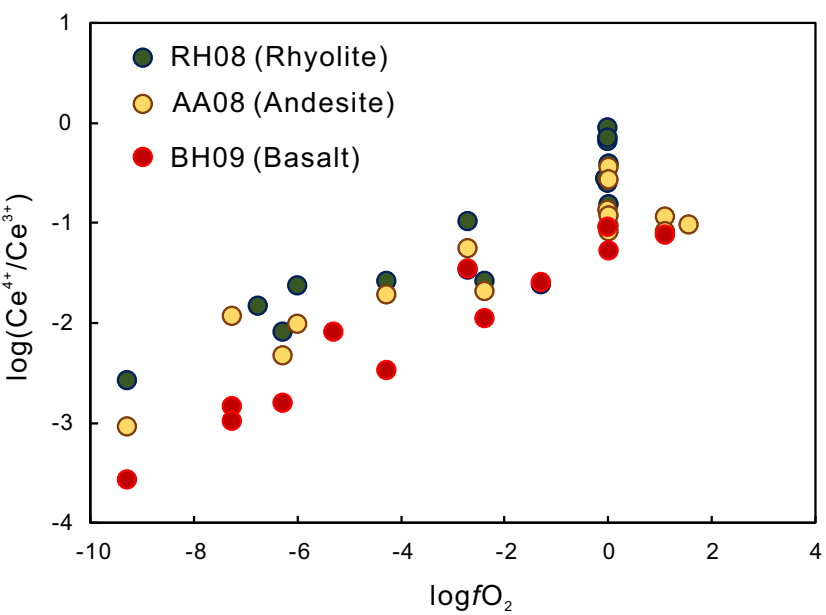

Fig. $6 \log \left(f \mathrm{O}_{2}\right)$ vs. $\log \left(\mathrm{Ce}^{4+} / \mathrm{Ce}^{3+}\right)$ for a series of synthesized glasses ranging in composition from basalt to rhyolite, under $f \mathrm{O}_{2}$ conditions varying from FMQ -4.0 to FMQ +8.4 , water contents from $<2.8$ to $9.1 \mathrm{wt} \%$ and temperatures from 1200 to $1500{ }^{\circ} \mathrm{C}$. Data are from Smythe and Brenan (2016) 
of LREE with MREE and heavy REE (HREE) entering from melt into zircon. This is hardly to be verified since $\mathrm{La}$ and $\mathrm{Pr}$ contents in measured zircons are commonly below the limits of detection of most analytical technologies. Alternatively, using the lattice-strain model of Blundy and Wood (1994), the zircon-melt partition coefficients for the LREE can be predicted, then the LREE values in the zircon can be calculated theoretically if melt compositions are known, which then can be compared to the values determined by our method. However, the exact composition of melts from which zircon crystallized is nearly inaccessible as discussed in the second section, even for experimental and/or natural phenocryst (zircon)-glass pairs.

Overall, although on-going works are still needed to demonstrate its effectiveness, the presented method provides a simple way to predict the magmatic oxidation state. In practice, the revised $\mathrm{Ce} / \mathrm{Ce}^{*}$ method is particularly important for analyses where the provenance of the analyzed zircon is unknown or in question (e.g., detrital zircons). It may also be important for analyses of rock samples from hydrothermal mineral deposits, which are generally strongly modified by hydrothermal alteration. In this case, zircons collected from rocks may be still of magmatic origin but whole rock geochemistry cannot represent the real melt from which the rock formed, let alone represent the melt where zircon crystallized. Moreover, for zircon studies where REEs are not fully provided, we can also use the logarithmic curve on chondritenormalized diagrams to give the missing REE concentrations, especially for the high atomic number REEs.

\section{Conclusions}

Although feasible in theory, both the existing $\mathrm{Ce} / \mathrm{Ce} *$ methods and the $\mathrm{Ce}^{4+} / \mathrm{Ce}^{3+}$ method proposed by Ballard et al. (2002) are problematic in practice and thus may not be a good proxy for the oxidation state of magmas. The correct $\mathrm{r}_{0}^{3+}$ for zircon lattice strain modelling is not $0.84 \AA$ and may approach $0.953 \AA$. A revised Ce/Ce* method is proposed in our study, which is based on the new finding that zircon REEs follow a logarithmic function in chondrite-normalized patterns. Application of this new method to published databases for zircons shows that it is suitable to estimate oxygen fugacity and more effective in discriminating fertile from barren rocks in porphyry $\mathrm{Cu}$ systems. The study also manifests that $\mathrm{La}$ contents in magmatic zircon should be generally very low (perhaps $<0.03 \mathrm{ppm}$ ) and many reported magmatic zircons with high La contents were probably just contaminated by small melt/mineral inclusions during analyses.

Acknowledgements We thank Antony Burnham and an anonymous expert for their constructive comments and journal editor Lutz Nasdala for the editorial handling. We would also like to thank Yannick Buret and
James Brenan for their suggestions for an early version of this manuscript. Chris Stanley kindly helped with improving English language. This study was financially supported by the Fundamental Research Funds for the Central Universities of China (201813026) and China Postdoctoral Science Foundation (20180838). RS acknowledges funding under Natural Environment Research Council Grant NE/P017452/1 "From arc magmas to ores (FAMOS): A mineral systems approach".

Open Access This article is distributed under the terms of the Creative Commons Attribution 4.0 International License (http:// creativecommons.org/licenses/by/4.0/), which permits unrestricted use, distribution, and reproduction in any medium, provided you give appropriate credit to the original author(s) and the source, provide a link to the Creative Commons license, and indicate if changes were made.

\section{References}

Ballard JR, Palin MJ, Campbell IH (2002) Relative oxidation states of magmas inferred from $\mathrm{Ce}(\mathrm{IV}) / \mathrm{Ce}(\mathrm{III})$ in zircon: application to porphyry copper deposits of northern Chile. Contrib Mineral Petrol 144:347-364

Barberi F, Bizouard H, Varet J (1971) Nature of the clinopyroxene and iron enrichment in alkalic and transitional basaltic magmas. Contrib Mineral Petrol 33:93-107

Bindeman IN, Serebryakov NS, Schmitt AK, Vazquez JA, Guan Y, Azimov PY, Astafiev BY, Palandri J, Dobrzhinetskaya L (2014) Field and microanalytical isotopic investigation of ultradepleted in ${ }^{18}$ O Paleoproterozoic "Slushball earth" rocks from Karelia Russia. Geosph 10:308-339

Blevin PL, Chappell BW (1992) The role of magma sources oxidation states and fractionation in determining the granite metallogeny of eastern Australia. Trans R Soc Edinb Earth Sci 83:305-316

Blundy J, Wood B (1994) Prediction of crystal-melt partition coefficients from elastic moduli. Nature 372:452-454

Blundy J, Wood B (2003) Mineral-melt partitioning of uranium thorium and their daughters. Rev Mineral 52:59-123

Burnham AD, Berry AJ (2012) An experimental study of trace element partitioning between zircon and melt as a function of oxygen fugacity. Geochim Cosmochim Acta 95:196-212

Burnham AD, Berry AJ (2017) Formation of hadean granites by melting of igneous crust. Nat Geosci 10:457-461

Claiborne LL, Miller CF, Wooden JL (2010) Trace element composition of igneous zircon: a thermal and compositional record of the accumulation and evolution of a large silicic batholith Spirit Mountain Nevada. Contrib Mineral Petrol 160:511-531

Colombini LL, Miller CF, Gualda GA, Wooden JL, Miller JS (2011) Sphene and zircon in the Highland range volcanic sequence (Miocene southern Nevada USA): elemental partitioning phase relations and influence on evolution of silicic magma. Mineral Petrol 102:29-50

Finch RJ, Hanchar JM, Hoskin PW, Burns PC (2001) Rare-earth elements in synthetic zircon: part 2 a single-crystal X-ray study of xenotime substitution. Am Mineral 86:681-689

Gardiner NJ, Hawkesworth CJ, Robb LJ, Whitehouse MJ, Roberts NMW, Kirkland CL, Evans NJ (2017) Contrasting granite Metallogeny through the zircon record: a case study from Myanmar. Sci Rep 7:748

Loader MA, Wilkinson JJ, Armstrong RN (2017) The effect of titanite crystallisation on $\mathrm{Eu}$ and $\mathrm{Ce}$ anomalies in zircon and its implications for the assessment of porphyry cu deposit fertility. Earth Planet Sci Lett 472:107-119

Luo Y, Ayers JC (2009) Experimental measurements of zircon/melt traceelement partition coefficients. Geochim Cosmochim Acta 73:36563679 
Mahood G, Hildreth W (1983) Large partition coefficients for trace elements in high-silica rhyolites. Geochim Cosmochim Acta 47:11-30

Marshall A, Macdonald R, Rogers N, Fitton J, Tindle A, Nejbert K, Hinton R (2009) Fractionation of peralkaline silicic magmas: the greater olkaria volcanic complex Kenya Rift Valley. J Petrol 50: 323-359

McDonough WF, Sun SS (1995) The composition of the earth. Chem Geol 120:223-253

Munoz M, Charrier R, Fanning C, Maksaev V, Deckart K (2012) Zircon trace element and $\mathrm{O}-\mathrm{Hf}$ isotope analyses of mineralized intrusions from El Teniente ore deposit Chilean Andes: constraints on the source and magmatic evolution of porphyry $\mathrm{Cu}-\mathrm{Mo}$ related magmas. J Petrol 53:1091-1122

Murali AV, Parthasarathy R, Mahadevan TM, Das MS (1983) Trace element characteristics REE patterns and partition coefficients of zircons from different geological environments - a case study on Indian zircons. Geochim Cosmochim Acta 47:2047-2052

Rubatto D, Hermann J (2007) Experimental zircon/melt and zircon/garnet trace element partitioning and implications for the geochronology of crustal rocks. Chem Geol 241:38-61

Sano Y, Terada K, Fukuoka T (2002) High mass resolution ion microprobe analysis of rare earth elements in silicate glass apatite and zircon: lack of matrix dependency. Chem Geol 184:217-230

Shen P, Hattori K, Pan H, Jackson S, Seitmuratova E (2015) Oxidation condition and metal fertility of granitic magmas: zircon traceelement data from porphyry cu deposits in the central Asian Orogenic Belt. Econ Geol 110:1861-1878

Smythe DJ, Brenan JM (2015) Cerium oxidation state in silicate melts: combined $\mathrm{fO}_{2}$ temperature and compositional effects. Geochim Cosmochim Acta 170:173-187

Smythe DJ, Brenan JM (2016) Magmatic oxygen fugacity estimated using zircon-melt partitioning of cerium. Earth Planet Sci Lett 453: 260-266

Takahashi Y, Sakashima T, Shimizu H (2003) Observation of tetravalent cerium in zircon and its reduction by radiation effect. Geophys Res Lett 30:1137

Thomas JB, Bodnar RJ, Shimizu N, Sinha AK (2002) Determination of zircon/melt trace element partition coefficients from SIMS analysis of melt inclusions in zircon. Geochim Cosmochim Acta 66:28872901

Trail D, Bruce WE, Tailby ND (2012) Ce and Eu anomalies in zircon as proxies for the oxidation state of magmas. Geochim Cosmochim Acta 97:70-87

Trail D, Tailby ND, Lanzirotti A, Newville M, Thomas JB, Watson EB (2015) Redox evolution of silicic magmas: insights from XANES measurements of Ce valence in bishop tuff zircons. Chem Geol 402: $77-88$

Trail D, Watson EB, Tailby ND (2011) The oxidation state of hadean magmas and implications for early Earth's atmosphere. Nature 480:79-82

Wood BJ, Blundy JD (1997) A predictive model for rare earth element partitioning between clinopyroxene and anhydrous silicate melt. Contrib Mineral Petrol 129:166-181

Wopenka B, Jolliff BL, Zinner E, Kremser DT (1996) Trace element zoning and incipient metamictization in a lunar zircon: application of three microprobe techniques. Am Mineral 81:902-912

Zhong SH, Feng CY, Seltmann R, Li D, Qu HY (2018) Can magmatic zircon be distinguished from hydrothermal zircon by trace element composition? The effect of mineral inclusions on zircon trace element composition. Lithos 314-315:646-657

Zhong SH, Seltmann R, Shen P (2017) Two different types of granitoids in the Suyunhe large porphyry Mo deposit NW China and their genetic relationships with molybdenum mineralization. Ore Geol Rev 88:116-139

Zhu JJ, Richards JP, Rees C, Creaser R, DuFrane SA, Locock A, Petrus JA, Lang J (2018) Elevated magmatic sulfur and chlorine contents in ore-forming magmas at the red Chris porphyry $\mathrm{Cu}-\mathrm{Au}$ deposit northern British Columbia Canada. Econ Geol 113:1047-1075

Zou XY, Qin KZ, Han X, Li GM, Evans NJ, Li ZZ, Yang W (2019) Insight into zircon REE oxy-barometers: a lattice strain model perspective. Earth Planet Sci Lett 506:87-96

Publisher's note Springer Nature remains neutral with regard to jurisdictional claims in published maps and institutional affiliations. 